\title{
Description of Sarcofahrtiopsis spinetta sp. nov. and new records of S. cuneata (Diptera: Sarcophagidae) in South America
}

\author{
Pablo Ricardo MULIERI ${ }^{1} \&$ Matías Ignacio DUFEK ${ }^{2}$
}

\begin{abstract}
${ }^{1}$ Consejo Nacional de Investigaciones Científicas y Técnicas (CONICET), Buenos Aires, Argentina. Museo Argentino de Ciencias Naturales "Bernardino Rivadavia" (MACN). Ángel Gallardo Av. 470, Buenos Aires, Argentina. ${ }^{2}$ Consejo Nacional de Investigaciones Científicas y Técnicas (CONICET). Universidad Nacional del

Nordeste, Facultad de Ciencias Exactas y Naturales y Agrimensura, Biología de los Artrópodos, Libertad St. 5470, Corrientes, Argentina.
\end{abstract}

\begin{abstract}
This work provides, for the first time, records of the genus Sarcofahrtiopsis Hall (Diptera: Sarcophagidae) in Argentina and Ecuador. A new species of the genus collected in the Humid Chaco ecoregion of Argentina is described, S. spinetta sp. nov. Also, we report new distributional records for S. cuneata (Townsend) from Argentina and Ecuador. A key including all the species of Sarcofahrtiopsis and comparative illustrations of the phallic structures, to diagnose and separate the species, are provided.
\end{abstract}

Key words: Sarcophagidae, Sarcofahrtiopsis, Neotropical Region, Argentina, Ecuador.

Resumen: El género Sarcofahrtiopsis Hall (Diptera: Sarcophagidae): descripción de S. spinetta sp. nov. y nuevos registros de S. cuneata en Sudamérica. Este trabajo incluye los primeros registros del género Sarcofahrtiopsis Hall (Diptera: Sarcophagidae) en Argentina y Ecuador. Se describe una nueva especie del género colectada en la ecorregión del Chaco Húmedo de Argentina, S. spinetta sp. nov. Asimismo, reportamos nuevos registros de distribución para $S$. cuneata (Townsend) de Argentina y Ecuador. Se brinda una clave de especies y se proporcionan ilustraciones comparativas de las estructuras del phallus para reconocer y separar las especies.

Palabras clave: Sarcophagidae, Sarcofahrtiopsis, Región Neotropical, Argentina, Ecuador.

\section{INTRODUCTION}

Sarcofahrtiopsis Hall comprises 16 species of flesh flies distributed predominately in Antillean Islands, Central America and northern areas of South America. Three species are known to extend outside this distribution: S. paterna Dodge in Cuba, Jamaica, and Puerto Rico, but also recorded in Florida (USA); S. farri Dodge, reaching Texas (USA); and S. cuneata (Townsend), which extends from Central America and the Antillean Islands to Rio de Janeiro (Pape, 1996; Pape \& Méndez, 2004; Carvalho-Filho et al., 2017).

Lopes $(1983,1990)$, in his tribal classification of the Sarcophaginae, included the genus Sarcofahrthiopsis as part of the tribe Sarothromyiini, with Bahamiola Dodge, Nephochaetopteryx Townsend, Rettenmeyerina Dodge and Tricharaea Thomson. A recent phylogenetic study consider Pacatuba Lopes as synonymy of Sarcofahrthiopsis, and places the genus Sarcofahrthiopsis with Bahamiola and Tricharaea as part of the Tricharaea grade, which corresponds to the first basal split of the Sarcophaginae (Buenaventura \& Pape, 2017). The genera of the Tricharaea grade share some morphological features not found outside this group (see Buenaventura \& Pape, 2017). Among them, the presence of proclinate fronto-orbital setae in males appears as one of the most striking external character states among Sarcophaginae, as was already observed by Lopes (1990).

Species of Sarcofahrtiopsis are small to medium-sized (3-6 $\mathrm{mm})$ and can be distinguished from other sarcophagine genera by the following combination of character states: one or two proclinate fronto-orbital setae in male; notopleuron with subprimary setae absent or reduced (occasional specimens with a single small subprimary seta); two katepisternal setae; postalar wall bare; metasternum with reduced setosity (the only autapomorfic character of the genus); third costal sector of wing bare ventrally; male hind coxa with posterior setulae bare or reduced (occasional specimens with one or a few setulae); male ST5 with posterior margin straight 
or with a shallow concavity; male ST5 with a central patch of setae; phallus with basi- and distiphallus connected by a desclerotized strip; armshaped lever of vesica very elongated (twice its full length) ventrally; arm-shaped lever of vesica with a hammer-shaped apex; distal section of vesica globose, with small denticles; acrophallus formed of a capitis, lateral styli and a median stylus; juxta hood-shaped, with ventral margin enlarged to form a globose and denticulated hood; spermathecae oval; female without an epiproct (Buenaventura \& Pape, 2017).

The biology of most of these flesh flies is unknown. Two species, namely $S$. thyropteronthos Pape, Dechmann \& Vonhof, and S. cupendipe Carvalho-Filho, Esposito \& Azevedo Silva, are associated with bat faeces in ephemeral roosts inside young and partially unfurled Heliconia and Calathea leaves (Pape et al., 2002; Carvalho-Filho et al., 2014); three species, S. carcini Pape \& Mendez, S. kuna Pape \& Mendez and $S$. chiriqui Pape \& Mendez were recorded as inhabiting coastal mangroves and breeding on semiterrestrial crabs (Pape \& Mendez, 2002, 2004).

In this paper we describe a new species of Sarcofahrtiopsis collected in the Humid Chaco ecoregion of northern Argentina. We further provide the first record of S. cuneata from Argentina and Ecuador, a key to all species in the genus and comparative illustrations of male genitalia, to diagnose and separate the species.

\section{MATERIAL AND METHODS}

Specimens of the new species were collected using van Someren Rydon traps baited with rotten squid in the province of Chaco $\left(27^{\circ} 12^{\prime} \mathrm{S}\right.$, $60^{\circ} 22^{\prime} \mathrm{W}$ ), Argentina, from 2015 to 2016 , and totalized 13 male specimens. These specimens were examined under a Leica S6D stereomicroscope. We pinned the specimens and their genitalia were exposed with entomological pins and minutens according to the technique described by Dahlem \& Naczi (2006). The habitus and genitalia were photographed using an Olympus DP 25 digital camera mounted on an Olympus SZX 16 stereomicroscope. In addition, the genitalia of a paratype were detached, macerated in $90 \%$ lactic acid, air-dried, and mounted on aluminum stubs for scanning electron microscopy (SEM) under high vacuum using a Philips XL Series 30 after gold-palladium coating.

Terminology follows McAlpine (1981) and Cumming \& Wood (2009) for external morphology and Mello-Patiu \& Pape (2000) and Giroux et al. (2010) for distiphallic structures. The terms "arm-shaped lever" of vesica is used as adopted by Buenaventura \& Pape (2017). Abbreviations: T, tergite; ST, sternite.

Voucher specimens of $S$. cuneata are housed at Universidad Nacional del Nordeste, Cátedra de Biología de los Artrópodos, Corrientes, Argentina (CARTROUNNE), and Museo Argentino de Ciencias Naturales "Bernardino Rivadavia," Buenos Aires, Argentina (MACN). The holotype of the new species is deposited at MACN. Paratypes are deposited at MACN and CARTROUNNE. Type specimen labels are quoted verbatim, with lines separated by a forward slash, labels separated by a semicolon, and comments given in square brackets.

The new records of $S$. cuneata are based on samples collected in the Humid Chaco ecoregion and on material from Brazil and Ecuador deposited at MACN. Information on material examined is provided as follows: number and sex of specimens, country, province or state, locality, geographic coordinates, date of collection, collector and depository (in brackets). Previous distribution records, presented at country and province or state level, are derived from Townsend (1935), Pape (1996), Mello-Patiu \& Pape (2000), Barbosa et al. (2009, 2017), Sousa et al. (2011), Yepes-Gaurisas et al. (2013), Carvalho-Filho et al. (2014), Pereira de Sousa et al. (2016) and Valverde-Castro et al. (2017).

\section{RESULTS}

\section{Sarcofahrtiopsis spinetta sp. nov.}

(Figs. 1A-D, 2, 3, 4, 5M)

Diagnosis (Male). Head with two proclinate fronto-orbital setae; wing with third costal sector bare ventrally; vein $R_{1}$ setulose in proximal half; mid femur with a posteroventral ctenidium; ST5 with posterior margin straight or with a shallow concavity; pregonite with strong and curved spine-like setae; parameral apodeme elongated; basiphallus with dorsal rows of spines ditally; distiphallus with proximal arm-shaped lever of vesica parallel to phallic tube, not very elongated; juxta with an apical process.

Male. Body length $=4.88-5.24 \mathrm{~mm}(\mathrm{~m}=5.06$ $\mathrm{mm}, \mathrm{n}=3$ ).

Head. Head length at antennal base 1.28-1.34 times $(\mathrm{m}=1.3, \mathrm{n}=3)$ head length at vibrissal level; parafacial and proclinate fronto-orbital plates with pale golden pruinosity; parafacial plate with a row of weak and small setulae; post- 

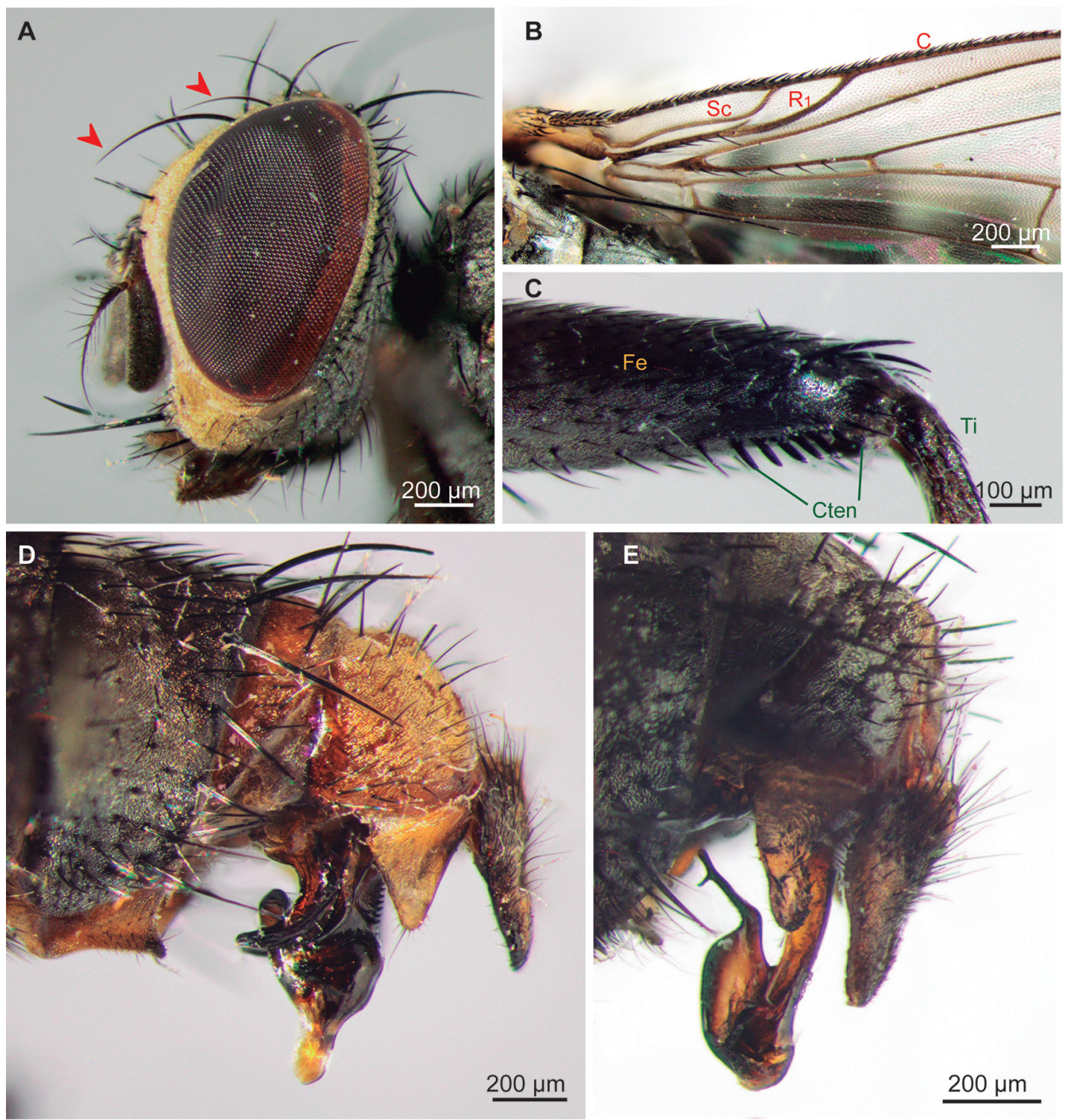

Fig. 1. A, Sarcofahrtiopsis spinetta, head, lateral view (red arrows indicating the proclinate fronto-orbital setae). B, S. spinetta, wing, anterobasal section. C, S. spinetta, apical section of mid femur, posterior view. D, S. spinetta (holotype, MACN), genitalia, lateral view. E, S. cuneata, genitalia, lateral view. Abbreviations: $C$, costa; Cten, ctenidium; Fe, femur; $R_{1}$, radial vein 1 ; $\mathrm{Sc}$, subcosta; Ti, tibia.

cranium with silvery-gray pruinosity, with two rows of black occipital setae parallel to postorbital setae; eyes bare; frontal vitta blackish in posterior part, brown near lunule; frons at its narrowest point $0.27-0.28$ times head width (m $=0.27, \mathrm{n}=3) ; 4-5$ frontal setae; one reclinate and two proclinate fronto-orbital setae; inner vertical setae strong and reclinate; outer vertical setae 0.5 times inner vertical and divergent; ocel- lar triangle black with yellowish microtomentum, with one pair of proclinate and slightly divergent ocellar setae; postocellar and paravertical setae present; postocular area with pale golden microtomentum; gena and genal dilation with pale golden pruinosity, with black setae; postgena with silvery pruinosity, with black setae and few pale setae poteriorly; face with silvery microtomentum; facial ridge with silvery microtomen- 
tum, with setae close to vibrissa; $3-4$ subvibrissal setae; antenna dark brown; first flagellomere dark blackish with gray microtomentum; length of first flagellomere 0.37-0.41 times head height $(\mathrm{m}=0.39, \mathrm{n}=3)$; arista plumose.

Thorax. Black. Prescutum and scutum with dorsal and lateral stripes of silvery-gray microtomentum, and three black stripes; postpronotal lobe with silvery-gray pruinosity; anepisternum with yellowish microtomentum; postpronotal lobe, notopleuron, anepimeron and katepisternum with silvery-gray microtomentum; proepisternum silvery, bare. Chaetotaxy: acrostichals $0+1$; dorsocentrals $2+3$; intra-alars $1+2$; supra-alars $1+3$ (the middle one stronger); postpronotals 2 ; postalars 2 ; notopleurals 2 ; two proespisternal setae (one weaker); one proepimeral seta; katepisternal setae 2 (plus one weaker in middle); postalar wall bare. Scutellum without apical setae, with one pair of subapical, one pair of basal and one pair of discal setae. Wing hyaline; vein $R_{1}$ setulose in proximal half; vein $\mathrm{R}_{4+5}$ setulose to crossvein $\mathrm{r}-\mathrm{m}$; costal spine not differentiated; third costal sector bare ventrally; cell $\mathrm{r}_{4+5}$ open; lower calypter whitish. Legs with coxae and trochanters brown with silvery-gray microtomentum; femora blackish with silverygray microtomentum; tibiae brown; tarsi brown; fore femur with a row of setae on dorsal, ventral, and posteroventral surfaces; mid femur with a posteroventral ctenidium in its apical portion, two median anterior setae, 2-3 basal anteroventral and 3-4 posteroventral setae; mid tibia with 1 anterodorsal and 2 posterodorsal setae; hind trochanter without a pad of short and stout setae; hind femur with rows of anterodorsal, anteroventral and posteroventral setae, and 1 preapical posterodorsal seta; hind tibia with 1 anteroventral, 2 anterodorsal, and 2 posterodorsal setae.

Abdomen. Tergites 1+2-4 black; T5 brown; sternites exposed; $\mathrm{T} 1+2$ with lateral spots of silvery microtomentum; T3-T5 with lateral and dorsal spots with silvery microtomentum; $\mathrm{T} 1+2-\mathrm{T} 3$ with one pair of lateral marginal setae; T4-T5 with a complete row of marginal setae; ST2-ST4 covered with gray microtomentum, with marginal setae not differentiated. ST5 with small median convexity on the posterior margin with a central patch of setae.

Genitalia. Syntergosternite $7+8$ reddish-orange with golden microtomentum, with 4-5 pairs of weak marginal setae; epandrium reddish-orange with golden microtomentum; cerci curved anteriorly at tip (lateral view) with rounded apex in dorsal view; cercal base 0.9 times as long as cercal prong (Fig. 3A); surstylus broad, triangular, with a rounded apex with sparse marginal and discal setulae; pregonite strongly sclerotized and curved with rough surface, with strong setae curved downward along its dorsal and apical margins (Fig. $2 \mathrm{~F}-\mathrm{G}$ ); postgonite shorter than pregonite, curved and sclerotized, with one strong seta; connection between basi- and distiphallus as a declerotized strip; basiphallus with dorsal rows of spines distally; proximal arm-shaped lever of vesica parallel to phallic tube, with a hammer-shaped apex (ventral view); distal section of vesica less sclerotized, with paired pointed projections distally; juxta with well-developed apical process (Figs. 2A, 2D, 3C); lateral styli and median stylus not exposed in lateral view (Fig. 3C).

Female. Unknown.

Etymology. The species epithet, which is a noun in apposition, is given in honor of Luis Alberto Spinetta, Argentine singer, guitarist and songwriter, one of the most influential rock musicians of Argentina.

Distribution. Argentina: Chaco (Fig. 4).

Type Material. Holotype male (MACN), [a piece of circled red label]; "Argentina, Chaco. / Villa Berthet 2713' / 28.3”'S, 60'22'49.7”W / 27VII-2015. Calamar 3. / Bosque, Col. M. I. Dufek. [printedon white paper]"; "Sarcofahrtiopsis spinetta / Holotype / Det. Mulieri and Dufek 2017 [printed on red paper]"; "Holotype [printed on red paper]". Specimen in good conditions, genitalia spread and exposed. Paratypes. One male (MACN), "Argentina, Chaco./Villa Berthet. 27¹3' / 28.3”S, 60²2'49.7”W / 27-VII-2015. Calamar 4 / Bosque, Col. M. I. Dufek [printed on white label]"; "Sarcofahrtiopsis spinetta / Paratype / Det. Mulieri and Dufek 2017 [printed on red paper]". Two males (CARTROUNNE), "Argentina, Chaco. Villa Berthet / $27^{\circ} 13^{\prime} 28.3^{\prime}$ 'S, 60²2'49.7”W / 27-VII-2015. Col. M. I. Dufek [printed on white label]"; "Sarcofahrtiopsis spinetta / Paratype / Det. Mulieri and Dufek 2017 [printed on red paper]". One male (CARTROUNNE), "Argentina, Chaco. Villa Berthet $/ 27^{\circ} 12^{\prime} 59.8^{\prime}$ 'S, $60^{\circ} 23^{\prime} 08.9^{\prime} \mathrm{W}$ / 27-VII-2015. Col. M. I. Dufek [printed on white label]"; "Sarcofahrtiopsis spinetta / Paratype / Det. Mulieri and Dufek 2017 [printed on red paper]". One male (MACN), "Argentina, Chaco. /

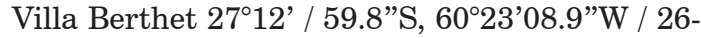
I-2016. Calamar 1. / Ganadero, Col. M. I. Dufek [printed on white label]"; "Sarcofahrtiopsis spinetta / Paratype / Det. Mulieri and Dufek 2017 [printed on red paper]".

Biology. Unknown. 

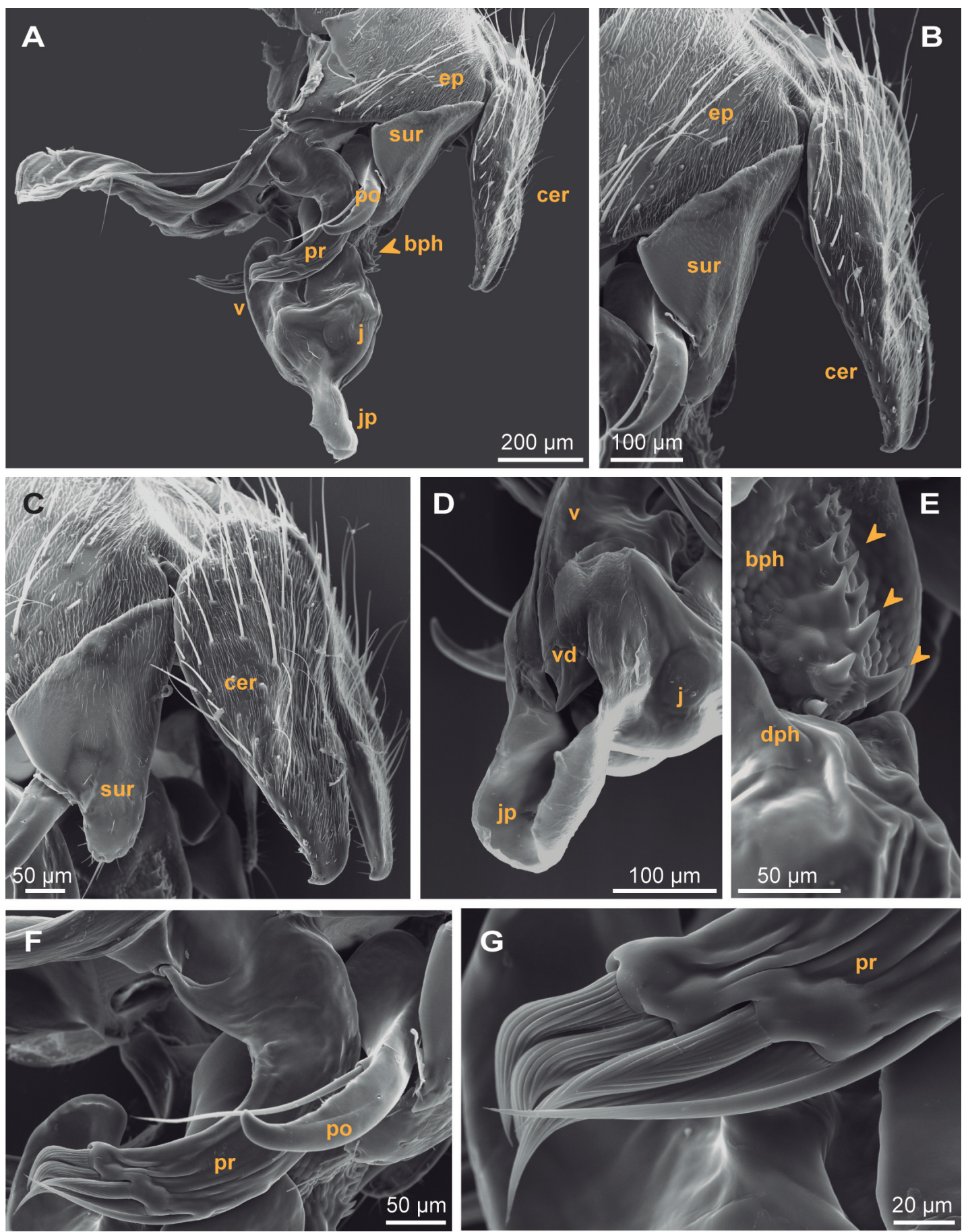

Fig. 2. Sarcofahrtiopsis spinetta (paratype, MACN), SEM images of genitalic structures. A, Genitalia, lateral view. B, Cercus and surstylus, lateral view. C, Cerci and sursytlus, dorso-lateral view. D, Distiphallus, apico-ventral view. E, Phallus, connection between basi- and distiphallus, dorso-lateral view (arrows indicating dorsal spines on basiphallus). F, Pregonite and postgonite, lateral view. G, Apical setae of pregonite, lateral view. Abbreviations: bph, basiphallus; cer, cercus; dph, distiphallus; ep, epandrium; j, juxta; jp, apical juxtal process; po, postgonite; pr, pregonite; sur, surstylus; v, vesica; vd, distal section of vesica. 


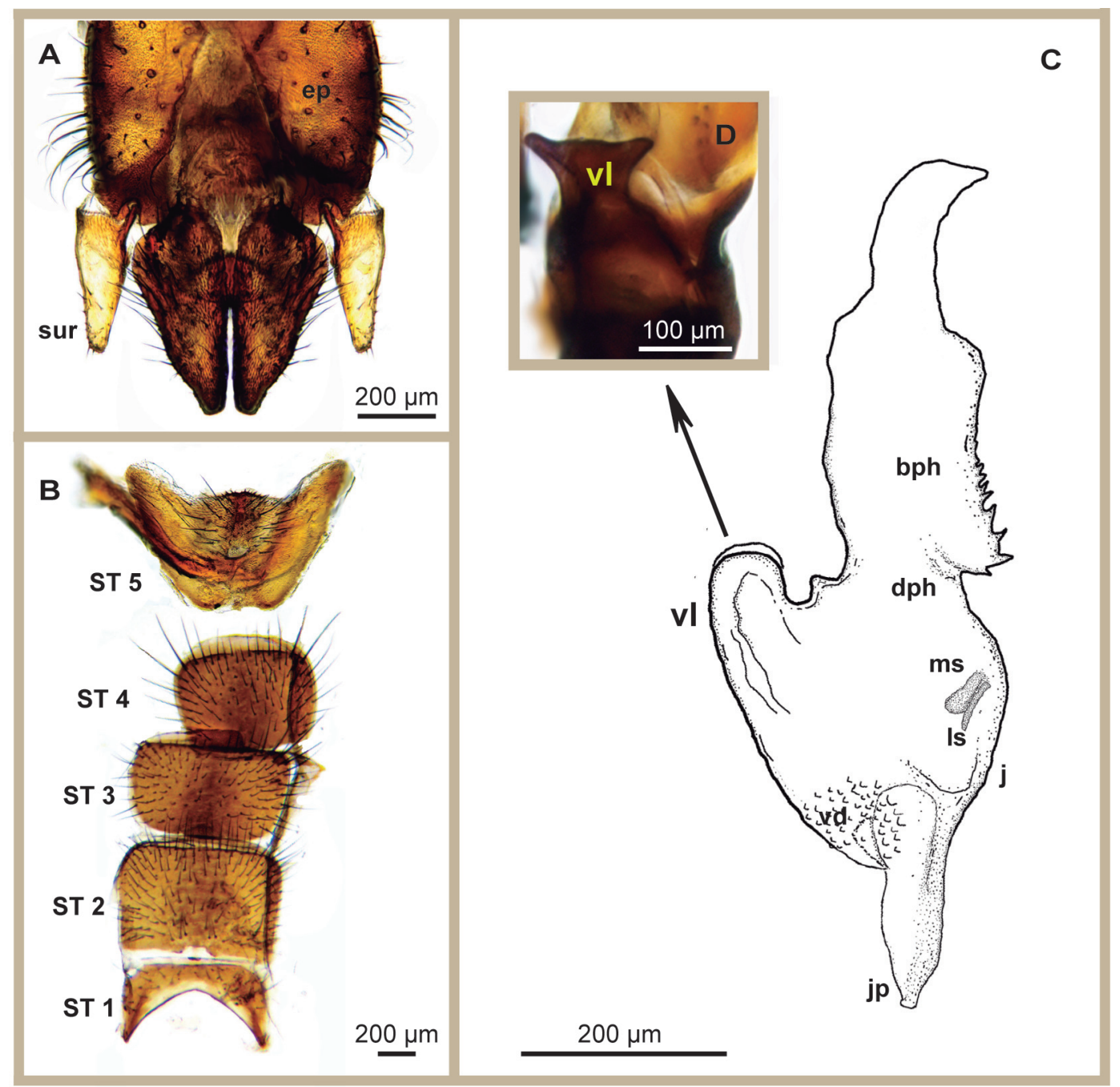

Fig. 3. Sarcofahrtiopsis spinetta (paratype, MACN), genitalic structures. A, Cerci and surstyli (dissected), dorsal view. B, Abdominal sternites (dissected), ventral view. C, Phallus, lateral view. D, Vesical arm-shaped lever, ventral view. Abbreviations: bph, basiphallus; dph, distiphallus; ep, epandrium; j, juxta; jp, juxtal process; ls, lateral stylus; ms, median stylus; ST, sternite; sur, surstylus; vd, distal section of vesica; vl, vesical arm-shaped lever.

Sarcofahrtiopsis cuneata (Townsend, 1935)

(Figs. 1E, 4, 5D)

Material examined: $1{ }^{\lambda}$, Argentina, Chaco, Villa Berthet, 27¹3'28.3"S 60²2'49.7”W, 27.III.2015, M. I. Dufek leg. (MACN); 3 ऽ, Argentina, Chaco,

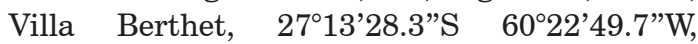
26.VI.2015, M. I. Dufek leg. (CARTROUNNE); 1 ơ, Argentina, Chaco, Villa Berthet, $27^{\circ} 13^{\prime} 23.0$ ”S $60^{\circ} 22^{\prime} 33.5$ ”'W, 27.VII.2015, M. I. Dufek

leg. (CARTROUNNE); 1 त, Argentina, Chaco, Villa Berthet, $27^{\circ} 13^{\prime} 23.0^{\prime \prime S} \quad 60^{\circ} 22^{\prime} 33.5^{\prime \prime} \mathrm{W}$, 27.VII.2015, M. I. Dufek leg. (MACN); 1 ,
Argentina, Chaco, Villa Berthet, $27^{\circ} 13^{\prime} 28.3^{\prime \prime S}$ 60²2'49.7”W, 26.I.2016, M. I. Dufek leg. (MACN); 1 ô, Brazil, Rio de Janeiro, Buzios,

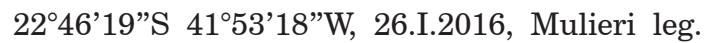
(MACN); 5 §ै, Ecuador, Sucumbíos, Lago Agrio, V.1976, Mariluis leg. (MACN).

Distribution. Argentina (new record): Chaco. Brazil: Amazonas, Ceará, Maranhao, Pará, Pernambuco, Rio de Janeiro. Colombia: Antioquia, Córdoba, La Guajira. Costa Rica: Limón. Dominica: Saint Joseph. Ecuador (new record): Sucumbíos. Trinidad \& Tobago: Trinidad. Venezuela: Aragua (Fig. 4). 


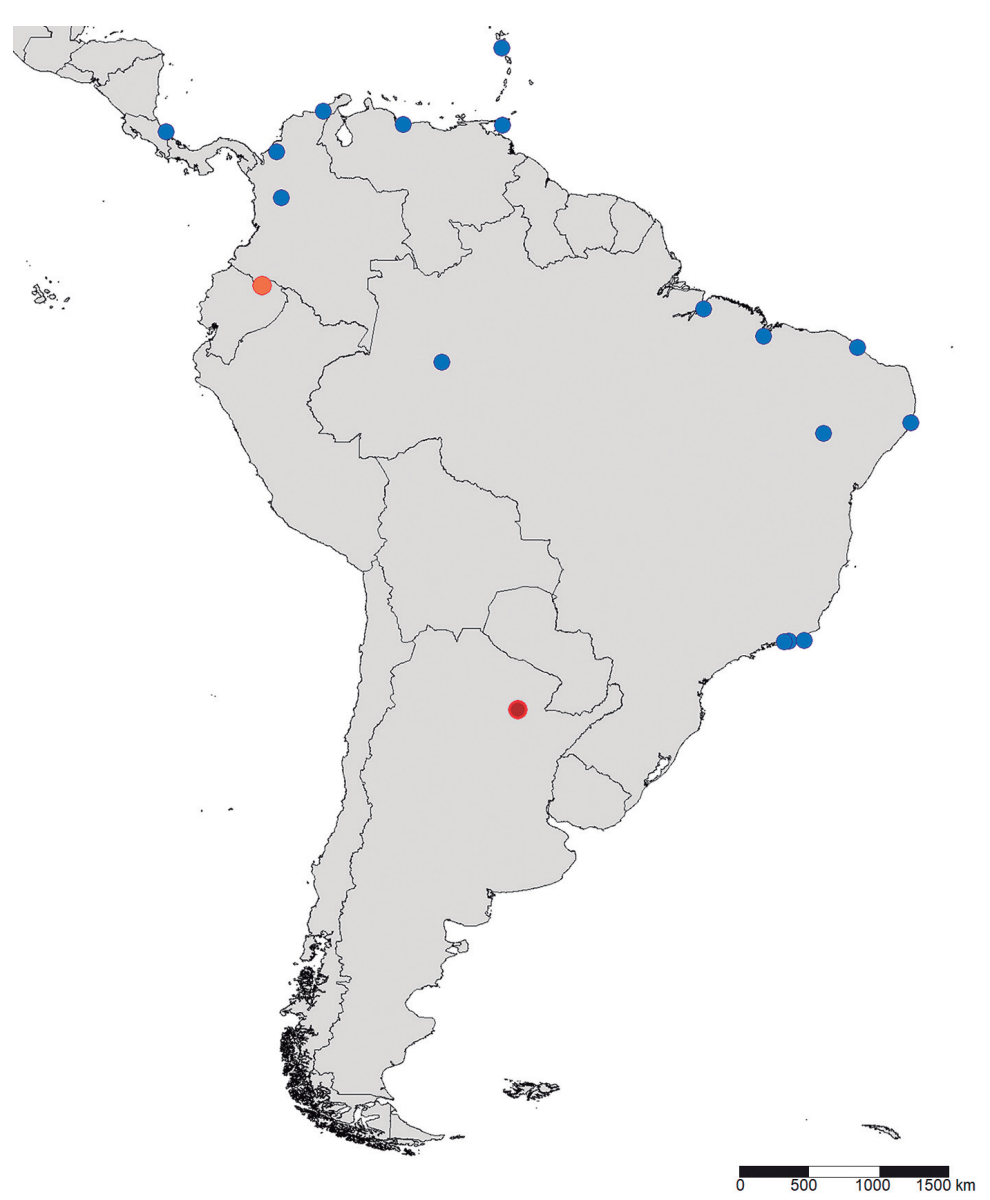

Fig. 4. Geographical distribution of Sarcofahrtiopsis cuneata and Sarcofahrtiopsis spinetta. Blue dots, previous records of $S$. cuneata; orange dot, new record of $S$. cuneata from Ecuador; red dot, new record of $S$. cuneata from Argentina and type locality of $S$. spinetta.

\section{Key to species of Sarcofahrtiopsis (males only)}

This is a modification of the keys provided by Méndez et al. (2008) and Carvalho-Filho et al. (2017).

Sarcofahrtiopsis diembroma Dodge was not included because only the female is known.

1. Mid femur with a ctenidium (Fig. 1C)

- Mid femur without a ctenidium

2. Vein $R_{1}$ bare. Basiphallus without spines dorsally. Arm-shaped lever of vesica very elongated and recurved (Fig. 5I) S. matthewsi (Lopes)

- Vein $R_{1}$ setulose in proximal half. Basiphallus with spines dorsally (Fig. 2E). Arm-shaped lever of vesica not very elongated (Fig. 5M). S. spinetta sp. nov.

3. Vein $R_{1}$ setulose along full length. Postgonal apodeme not elongate [Figure 3 in Carvalho-Filho et al. (2014)]

- Vein $R_{1}$ setulose in proximal half. Postgonal apodeme distinctly elongate [Figures 13 and 22 in Mello-Patiu \& Pape (2000)].

4. Distiphallus without cuticular spines laterally (Fig. 5E). Postgonite with tip strongly curved [Figure 3 in Carvalho-Filho et al. (2014)]. Surstylus without spines in basal half [Figure 1 in Carvalho-Filho et al. (2014)]..... S. cupendipe Carvalho-Filho \& Esposito 
- Distiphallus with minute cuticular spines laterally (Fig. 5O). Postgonite with tip gently curved [Figure 3 in Pape et al. (2002)]. Surstylus with spines in basal half [Figure 1 in Pape et al. (2002)] S. thyropteronthos Pape, Dechmann \&Vonhof

5. Abdominal T 5 reddish 6

- Abdominal T 5 black. .7

6. Vesica with distal section smoothly rounded or broadly oval. S. baumhoveri Dodge

- Vesica with distal section irregular, with a median row of teeth or denticles (Fig. 5K) S. piscosa Méndez, Mello-Patiu \& Pape

7. Vesica with distal section bearing a spiny process in addition to the arm-shaped lever (Fig. 5J) S. paterna Dodge

- Vesica without an additional spiny process distally, having only the arm-shaped lever....................8

8. Arm-shaped lever of vesica with a small or a large bifurcation (Figs. 5B-D, 5H) ...........................

- Arm-shaped lever of vesica simple, without a bifurcation ...............................................................12

9. Arm-shaped lever of vesica with a small bifurcation, as a subapical barb- or thorn-like process (Figs. 1E, 5D). S. cuneata (Townsend)

- Arm-shaped lever of vesica with a large bifurcation, both prongs of about equal length (Figs. $5 \mathrm{~B}-\mathrm{C}, 5 \mathrm{H})$

10. Cercus slightly swollen and compressed distally, tip blunt (lateral view) [Figure 3 in Pape \& Méndez (2002)] S. carcini Pape \& Méndez

- Cercus gradually tapering, tip pointed (lateral view) [Figures 3 and 6 in Pape \& Méndez (2004)]

11. Arm-shaped lever of vesica with bifurcation with prongs of about equal length, the one perpendicular to the longitudinal axis of the vesica set close to base of the arm-shaped lever (Fig. 5H)

S. kuna Pape \& Méndez

- Vesical arm-shaped lever with bifurcation with prongs of subequal length, the one perpendicular to the longitudinal axis of the vesica shortest and set just proximal to middle of the arm-shaped lever (Fig. 5C) S. chiriqui Pape \& Méndez

12. Vesical arm-shaped lever much longer than the rest of the vesica and with a spade- or shovellike flattened tip (Fig. 5L) S. spathor Mello-Patiu \& Pape

- Vesical arm-shaped lever at most as long as the rest of the vesica, tip not flattened . .13

13. Vesica rounded or broadly oval (Fig. 5A) .

S. capitata (Curran)

- Vesica more irregular, almost triangular (Fig. 1D)....

14. Distal section of vesica with long (about one-third of total vesical length of vesica or less) toe-like projections on apical margin (Fig. 5N). Surstylus with distal portion curved posteriorly [Figure 1A Carvalho-Filho et al. (2017)]. Basicosta brown ... S. terezinhae Carvalho-Filho, Souza \& Soares

- Distal section of vesica with very small (less than a fifth of total length of vesica) spine-like projections on apical margin (Figs. 5F-G). Surstylus with distal portion not curved posteriorly [Figures 22 and 25 in Dodge (1965)]. Basicosta brown or yellowish.

15. Basicosta yellowish. Distal section of vesica with 4 to 5 spines on apical margin (Fig. $5 \mathrm{~F}$ ) .........

- Basicosta brown. Distal section of the vesica with 8 to 10 spines on apical margin (Fig. 5G) ........ 


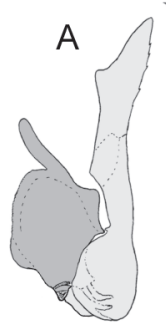

capitata

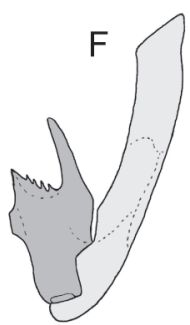

farri

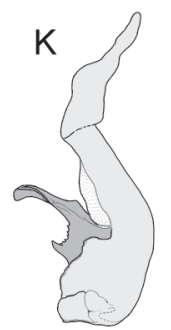

piscosa

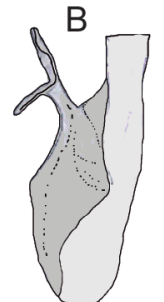

carcini

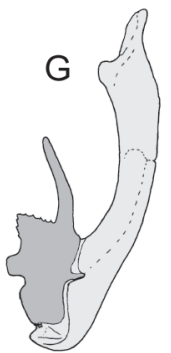

jamaicensis

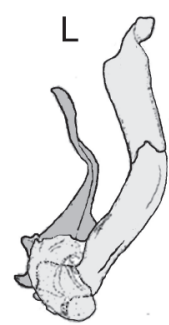

spathor

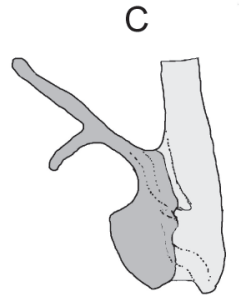

chiriqui

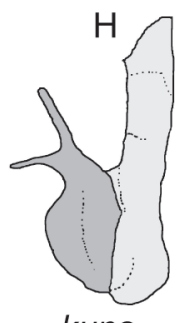

kuna

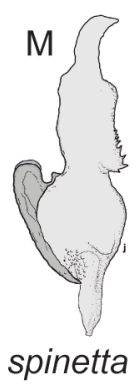

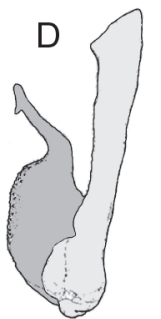

cuneata

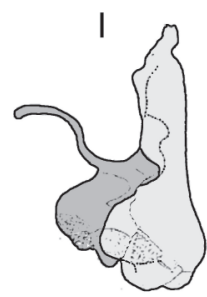

matthewsi

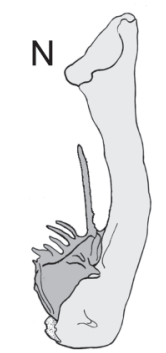

terezinhae

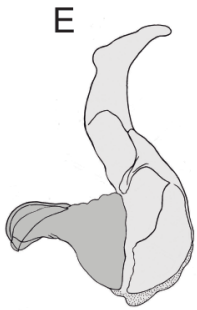

cupendipe

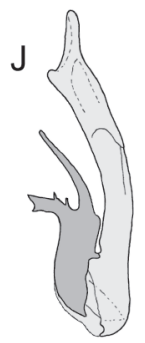

paterna

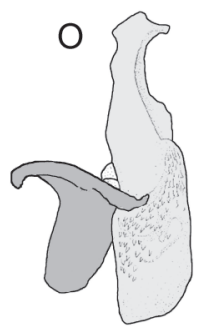

thyropteronthos

Fig. 5. Phallic morphology of species of Sarcofahrtiopsis (lateral view). A, S. capitata. B, S. carcini. C, S. chiriqui. D, S. cuneata. E, S cupendipe. F, S. farri. G. S. jamaicensis. H, S. kuna. I, S. matthewsi. J, S. paterna. K, S. piscosa. L, S. spathor. M, S. spinetta. N, S. terezinhae. O, S. thyropteronthos. Darker grey structures represent the vesica (Sarcofahrtiopsis baumhoveri Dodge was not included in this figure because its phallic structures are not known).

\section{DISCUSSION}

Buenaventura \& Pape (2017) proposed a subgeneric classification of the genus Sarcofahrtiopsis. According to their classification, the subgenus Pacatuba Lopes has male mid-femur with a ctenidium of rounded spines (circular cross section); wing vein $\mathrm{R}_{1}$ bare dorsally; and metasternum setulose. The subgenus Sarcofahrtiopsis has male mid-femur without a ctenidium; wing vein $R_{1}$ setulose dorsally; and metasternum with reduced setosity. Given that $S$. spinetta sp. n. possesses both a ctenidium and wing vein $R_{1}$ setulose, we chose not to place the new species in either of the subgenera, and we think a more comprehensive phylogenetic analysis, incorporating additional species of Sarcofahrtiopsis, will be necessary to elucidate relationships between the species in this genus. Phallic morphology is crucial to recognize the species of Sarcofahrtiopsis, and the structure and shape of the vesica reveals remarkable differences among species and represents the most useful character set allowing species identification.

This work provides, for the first time, records of the genus Sarcofahrtiopsis in Argentina and Ecuador. The new species, S. spinetta, were collected in well-preserved areas of savanna and forest in the Humid Chaco ecoregion. The new records of $S$. cuneata expand its distribution to western Ecuador and northern areas of Argentina, highlighting the wide distribution of this species compared to other species in the genus, which have smaller ranges and are usually restricted to coastal areas. 


\section{ACKNOWLEDGEMENTS}

This research was funded by the Secretaría General de Ciencia y Técnica, Universidad Nacional del Nordeste (16F020) and Agencia Nacional de Promoción Científica y Tecnológica (PICT 2016-3185). The authors wish to thank Fabian Tricarico (MACN) for providing support with SEM. P. R. Mulieri is a Career Researcher of CONICET; M. I. Dufek holds a scholarship from CONICET.

\section{BIBLIOGRAPHY}

Barbosa, R.R., C.A. Mello-Patiu, R.P.D. Mello \& M.M.D.C. Queiroz. 2009. New records of calyptrate dipterans (Fanniidae, Muscidae and Sarcophagidae) associated with the decomposition of domestic pigs in Brazil. Memórias do Instituto Oswaldo Cruz 104: 923-926.

Barbosa, T.M., R.F.R. Carmo, L.P. Silva, R.G. Sales \& S.D. Vasconcelos. 2017. Diversity of sarcosaprophagous calyptratae (diptera) on sandy beaches exposed to increasing levels of urbanization in Brazil. Environmental entomology 46: 460-469.

Buenaventura, E. \& T. Pape. 2017. Phylogeny, evolution and male terminalia functionality of Sarcophaginae (Diptera: Sarcophagidae). Zoological Journal of the Linnean Society 20: 1-99.

Carvalho-Filho, F.D.S., M.C. Esposito \& M.D.A. Silva. 2014. A further new species of Sarcofahrtiopsis Hall (Diptera: Sarcophagidae) associated with faeces of the disk-winged bat (Thyroptera spix: Chiroptera) in Brazil and the redescription of the female terminalia of $S$. cuneata (Townsend). Zootaxa 3889(1): 118-126.

Carvalho-Filho, F.D.S., C.C.D. Souza \& J.M.M. Soares. 2017. A new species of Sarcofahrtiopsis (Insecta, Diptera, Sarcophagidae) from mangrove forests in the Brazilian Amazon, with a key to species identification. Acta Amazonica 47(4): 349-354.

Cumming, J.M. \& D.M. Wood. 2009. Adult morphology and terminology. En: B.V. Brown, A. Borkent, J.M. Cumming, D.M. Wood, N.E. Woodley \& M.A. Zumbado (eds.), Manual of Central American Diptera. Vol. 1, pp. 9-50, NRC Research Press, Ottawa, Canada.

Dahlem, G.A. \& R.F.C. Naczi. 2006. Flesh flies (Diptera: Sarcophagidae) associated with North American pitcher plants (Sarraceniaceae), with descriptions of three new species. Annals of the Entomological Society of America 99: 218-240.

Giroux, M., T. Pape \& T.A. Wheeler. 2010. Towards a phylogeny of the fleshflies (Diptera: Sarcophagidae): Morphology and phylogenetic implications of theacrophallus in the subfamily Sarcophaginae. Zoological Journal of the Linnean Society 158: 740-778.

Dodge, R.H. 1965. The Sarcophagidae (Diptera) of the West Indies. II. Jamaica. Annals of the Entomological Society of America 58(4): 497-517.

Lopes, H.S. 1983. The importance of the mandible and clypeal arch of the first instar larvae in the clas- sification of the Sarcophagidae (Diptera). Revista Brasileira de Entomologia 26: 293-326.

Lopes, H.S. 1990. On the genera of Sarcophagidae (Diptera) showing proclinate frontorbital bristles in male. Revista Brasileira de Biologia 50(1): 279-292.

McAlpine, J.F. 1981. Morphology and terminologyadults. En: J.F. McAlpine, B.V. Peterson, G.E. Shewell, H.J. Teskey, J.R. Vockeroth \& D.M. Wood (eds.), Manual of Nearctic Diptera. Vol. 1, pp. 9-63, Agriculture Canada Monograph, Ottawa, Canada.

Mello-Patiu, C.A. \& T. Pape. 2000. Definitions of Dexosarcophaga Townsend, 1917 and Sarcofartiopsis (Hall, 1933), including two new species and redescriptions of Sarcofartiopsis cuneata (Townsend, 1935) (Diptera, Sarcophagidae). Boletín de Entomología Venezolana 15: 181-194.

Méndez, J., C.A. Mello-Patiu \& T. Pape. 2008. New flesh flies (Diptera: Sarcophagidae) from coastal mangroves of Panama with taxonomic notes and keys. Journal of Natural History 42: 249-257.

Pape, T. 1996. Catalogue of Sarcophagidae of the world (Insecta: Diptera). Memoirs on Entomology International 8: 1-558.

Pape, T. \& J. Méndez. 2002. A new species of Sarcofahrtiopsis Hall, 1933 from Panama (Diptera: Sarcophagidae). Annales Zoologici 52(2): 339-342.

Pape,T.\&J.Méndez.2004.TwonewspeciesofSarcofahrtiopsis (Diptera: Sarcophagidae). Zootaxa 485: 1-7.

Pape, T., D. Dechmann \& M.J. Vonhof. 2002. A new species of Sarcofahrtiopsis Hall (Diptera: Sarcophagidae) living in roosts of Spix's disk-winged bat Thyroptera tricolor Spix (Chiroptera) in Costa Rica. Journal of Natural History 36: 991-998.

Pereira de Sousa, J.R., F.D.S. Carvalho-Filho, L. Juen \& M.C. Esposito. 2016. Evaluating the effects of different vegetation types on necrophagous fly communities (Diptera: Calliphoridae; Sarcophagidae): implications for conservation. PLoS One 11: e0164826.

Sousa, J.R.P., M.C. Esposito \& F.D.S. Carvalho-Filho. 2011. Composition, abundance and richness of Sarcophagidae (Diptera: Oestroidea) in forests and forest gaps with different vegetation cover. Neotropical entomology 40: 20-27.

Townsend, C.H.T. 1935. New muscoid genera, mainly from the Neotropical Region. Revista de Entomología 5: 68-74.

Valverde-Castro, C., E. Buenaventura, J.D. SánchezRodríguez \& M. Wolff. 2017. Flesh flies (Diptera: Sarcophagidae: Sarcophaginae) from the Colombian Guajira biogeographic province, an approach to their ecology and distribution. Zoologia (Curitiba) 34: e12277.

Yepes-Gaurisas, D., J.D. Sánchez-Rodríguez, C.A. Mello-Patiu \& M. Wolff. 2013. Synanthropy of Sarcophagidae (Diptera) in La Pintada, AntioquiaColombia. Revista de Biología Tropical 61(3): 1275-1287.

Doi: 10.22179/REVMACN.21.641

Recibido: 20-V-2019

Aceptado: 26-X-2019 